\title{
アカデミア発シーズ開発に不可欠な連携 アカデミアにおけるシーズ開発と研究者のための連携
}

長村 文孝

要約：自社内のみで開発から市販までを完結するク ローズドイノベーションは, 特に創薬に関しては世界 的に行き詰まりをみせ，外部機関と広く連携を行う オープンイノベーションが推進されている。一方，ア カデミアの基礎研究力を活かした新規治療法の開発が 着目され，政府の支援も拡大している。アカデミアも 従来の自機関内での開発では非効率的であるだけでは なく, 必要なインフラの整備あるいは開発に必要な専 門家の確保等の問題により, 広く連携を行うことが不 可欠となってきている. アカデミア間の連携促進のた めに国からの競争的資金も導入されるようになり，ま た，他施設との共同利用型の設備あるいは体制整備も 進んでいる。本章では, このようなアカデミアでの連 携, すなわち, オープンイノベーションの推進の現状, そしてそれと密接に関連したアカデミアでのシーズ開 発についてまとめる.

\section{1.はじめに}

平成 27 年度にいわゆる「日本版 NIH」と言われた 日本医療研究開発機構が発足し, 日本の医療分野を中 心として国の研究開発のマネジメントが大きく変わる ことになった。この新体制では内閣総理大臣を本部長 とする健康・医療戦略推進本部が設置され, 健康 - 医 療分野の成長政略の推進と, 医療分野の研究開発に関 する総合戦略策定と研究開発関連予算の総合的な配分 調整を行うことになっている。平成 26 年 7 月に健康 ・ 医療戦略推進本部より「医療分野研究開発推進計画」 が発出され, 「近年, 開発費が高騰し, 一企業のみで医 療分野に関する研究開発を実施することは困難になり つつあることから, 大学, 研究機関, 病院, 企業等が ネットワークを形成し, 連携することの重要性が増し ている。限られた予算をいかに有効に医療・医療産業
に応用するかを考慮し，テーマを設定するとともに， 知的財産を確保しつつ, オープンイノベーションを実 現する取組が必要である.」と明記され，オープンイノ ベーションの重要性が指摘されている(1).ここでは, オープンイノベーションの定義は「外部の開発力ゃア イデアを活用することで課題を解決し，これまでにな い価值を生み出すこと」とされている。このように オープンイノベーションは, 我が国の医療政策に大き な影響を与えているが，もともとは製薬企業を中心と して広まった概念である。

\section{2. オープンイノベーションとは}

「オープンイノベーション (Open Innovation)」は 2003 年に Henry Chesbrough により提唱された (2). 従来, 医薬品開発は, 創薬の基となる化合物の発見や スクリーニングあるいは合成等のシーズ探索から承認 までの開発は 1 つの企業が一貫して行うことが通例で あった.この形態は，機密保持には都合がよく，また 1 社で利潤を独占できるという利点もあった. Henry Chesbrough はこのように 1 社で完結する開発の形態 を「クローズドイノベーション (Closed Innovation)」 と呼んだ。「オープンイノベーション」はこれと対局 の概念であるが，提唱された時代背景として，ブロッ クバスターと呼べる大型新薬の承認は激減し, 従来の 主力商品は特許切れを控えていたため, 開発手法にお いて大きな変革が求められていたことが関与している. 実際，2004 年に米国医薬品食品庁（FDA：Food and Drug Administration) は “Challenge and Opportunity on the Critical Path to New Medical Products”を発出し, 新規開発の停滞に対する懸念と, 規制当局として非臨 床試験から承認に至る段階での開発促進のための対応 への決意を表している。この白書では, 眓 $1 \mathrm{~A} に$ 示さ

キーワード：オープンイノベーション，アカデミア，シーズ，トランスレーショナルリサーチ

東京大学 医科学研究所 先端医療研究センター 先端医療開発推進分野（下108-8639 東京都港区白金台 4-6-1）

E-mail: nagamura@ims.u-tokyo.ac.jp＼cjkstart原稿受領日：2015 年 1 月 15 日，依頼原稿

Title: Collaboration between academia for the development of translational research Author: Fumitaka Nagamura 
れるように製薬企業の R\&D 予算と研究支援に関連す る NIH（National Institutes of Health）の予算は, 1993 年を 100 とした場合, 2002 年には倍以上に増加してい ることを指摘している.ところが図 1B に示されるよ うに, 米国 FDAによって承認された薬剤は医薬品, 生

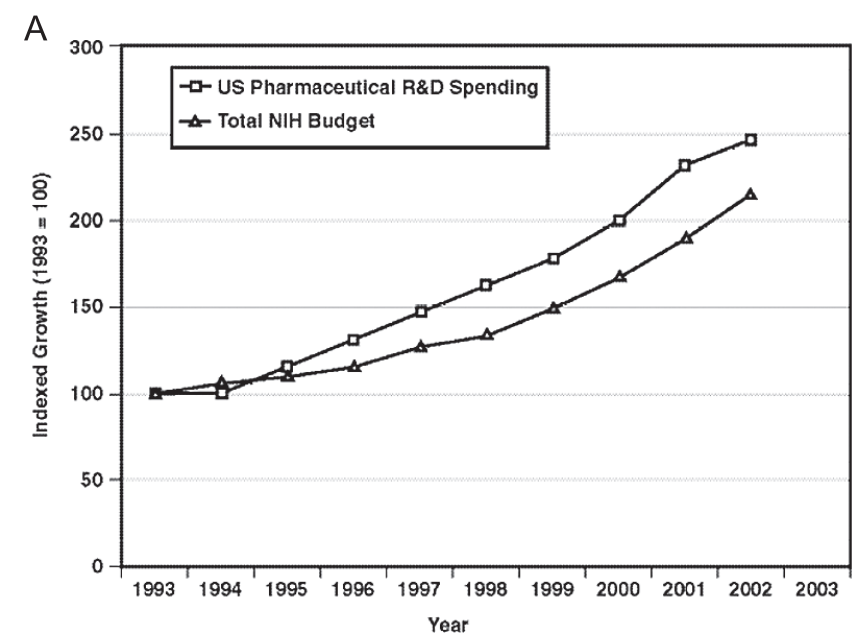

B

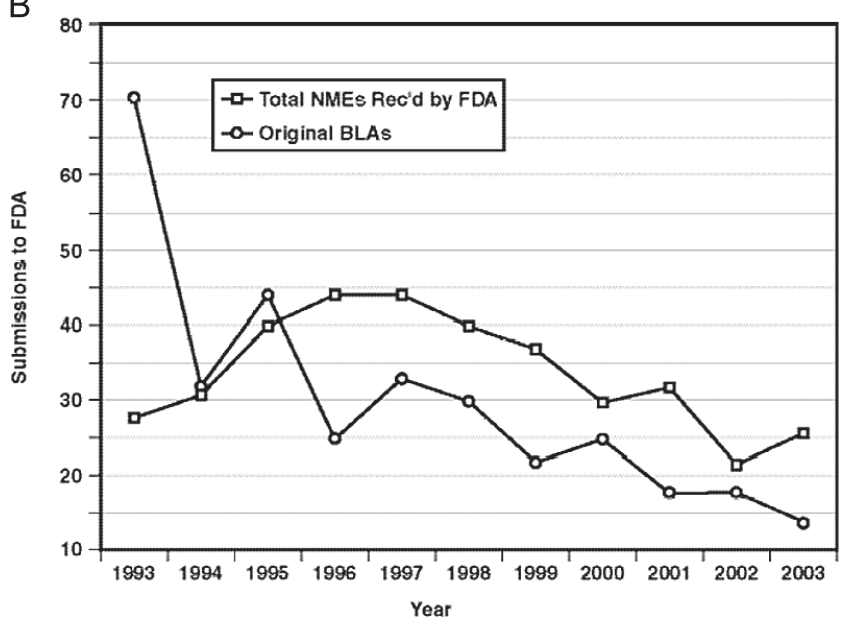

図 1 米国製薬企業の R\&D 投資額と NIH 予算の伸び (A) および 米国 FDA による承認品目数の減少 (B)

A : 1993 年を 100 とした場合の米国製薬企業のR\&D投資額が四角 $(\square)$ で, NIH (National Institutes of Health) の予算額が三角 $(\triangle)$ で 示されている. B : 1993 年から2003 年までの米国 FDA (Food and Drug Administration) による承認品目数. 医薬品は四角 ( $\square$ )で示さ れ，生物製剤は丸（○）で示されている.
物製剂共に右肩下がりに減少している。このような状 況を打破する概念として, オープンイノベーションは 提唱された。ある企業が見いだした候補品（シーズ） が存在した際に, 社外の人材やアイデア等を利用し, マーケットに至るまで連携関係を続け，お互いの利益, すなわち “Win-win の関係”を築き，解決困難であった 障壁を乗り越えたり，新たな価值を見いだす概念であ る.オープンイノベーションとクローズドイノベー ションの対比について Henry Chesbrough は表 1 のよ うにまとめている(3). また，オープンイノベーショ ンは企業のみに当てはまる概念ではなく, アカデミア を含めて, 外部のリソースやアイデアの活用・導入を 行うことを含んでいる.

\section{3. 製薬企業におけるオープンイノベーション}

日本では 1990 年代以降, 大手外資系製薬企業は国 内研究所を閉鎖し, 国内製薬企業も規模の縮小や海外 研究所への統合が行われ, 国内での研究開発力は低下 したといわれている。 また, メガ・ファーマであって もべンチャー企業の買収あるいは大学との共同研究に より開発力を維持しており, そのため, シーズの発掘 の重要性が非常に増している。このような背景から,

アカデミアを対象とした公募により, 創薬のシーズを 集めることが広く行われるようになっている. アカデ ミアが注目された理由としては, 創薬のシーズの開発 手法として，化合物の収集とそのスクリーニングによ る開発手法が行き詰まりを見せ始めている一方, キー となる分子を標的とした分子標的薬の開発やゲノム情 報の応用，あるいは，再生医療等の細胞を用いた製郕 等, 病因・病態の基礎研究の急速な進展を基に臨床応 用を目指す開発（「TR：トランスレーショナルリサー チ」あるいは「橋渡し研究」と呼ばれる) が盛んになっ ていることが挙げられる.

製薬企業のオープンイノベーションの例としては, アステラス製薬の $「 \mathrm{a}^{3}$ (エーキューブ)」, 第一三共株

表 1 オープンイノベーションとクローズドイノベーションの概念の対比

\begin{tabular}{|c|c|}
\hline クローズドイノベーション & オープンイノベーション \\
\hline 自社の優秀な人材が自社のために働く. & 企業内外の優秀な人材と働く. \\
\hline $\begin{array}{l}\text { R\&Dから利潤を得るためには自分たちでシーズを見つけ, 開発し, } \\
\text { 市販しなくてはならい. }\end{array}$ & $\begin{array}{l}\text { 外部との R\&D は著しい価値をもたらす，その場合，内部の R\&D } \\
\text { はその価值の一定の権利を有していることを主張するのに必要. }\end{array}$ \\
\hline シーズを発見したら， 最初に市販化する。 & シーズを発見しなくても利潤を得ることができる. \\
\hline 最初に市販化した企業が勝利を得る。 & $\begin{array}{l}\text { 最初に市販化するよりも, よりよいビジネスモデルを構築するほ } \\
\text { うが利益を得ることができる. }\end{array}$ \\
\hline 最も優れたアイデアを考えついた企業が勝つ. & 内外のアイデアを最も活用できた企業が勝つ. \\
\hline 他企業が自社の知財権を使用できないように管理する。 & $\begin{array}{l}\text { 他企業が自社の知財を利用することで利益を得る。自社のビジネ } \\
\text { スモデルに役立つなら何時でも他社の知財を購入する。 }\end{array}$ \\
\hline
\end{tabular}


式会社の「TaNeDS (タネデス)」等が挙げられる。こ れらは一般公募型であり，アカデミア等を広く対象と している. また, 特定のアカデミアと包括的契約締結 も行われている，契約の状況は様々であるが，契約企 業がアカデミアの創薬のシーズに優先的にアプローチ することができ，大学側は研究費や知財管理における 優遇等を受ける契約が多い. 企業としては研究者に個 別に接触する手間と時間を最小限に抑えるメリットも ある。例えば米国ファイザー社が東京大学と創薬共同 研究に扔ける戦略的パートナーシップ契約を締結した ことを挙げられる. 同社はこの契約への期待として 「ファイザー社が日本の最先端の大学での学術研究に アクセスできることで, 革新的な新薬の研究開発を行 う可能性が広がり，日本のみならず世界の医療に対し て恩恵となり得る」,「日本初の革新的な医薬品がいち 早く開発され，日本そして世界の多くの医療アンメッ トニーズの解決に貢献できる」を挙げ，大学側のメ リットとして「創薬に応用可能な学術研究の成果を効 率的に応用化研究へ進めることができる」を挙げてお り，相互にメリットがあるとしている(3)。また，シー ズの発掘だけではなく, 臨床試験実施のための包括的 契約も行われている。 アストラゼネカ社は国立がん研 究センターと臨床試験実施に関する包括的契約を締結 しているが「第 I 相試験を含む国際共同治験の推進も 目指しています」とされている(4).人体に初めて投 与する段階である第 I 相試験では, 有害事象への対応, 投与量・スケジュール等の見直し等の専門的知識が必 要であるが，集約化することによりノウハウを高める ことが期待できる.

企業主導治験は，かつては開発企業がほとんどの業 務を実施することが主流であった，しかし，治験が大 規模化, あるいはデザインも複雑になるにつれ, 臨床 試験の品質管理・品質保証業務であり専門性を必要とす るモニタリングや監査だけではなく, 治験実施そのもの を外部機関である CRO (Contact Research Organization, 医薬品開発業務受託機関）に委託する例が増加してい る.このような場合も外部機関の人材やノウハウを利 用し，また，当該の治験実施に最も相応しい機関を選 択することができることからオープンイノベーション に含められている.

\section{4. アカデミアにおけるオープンイノベーション}

アカデミアにおける基礎研究では使用機器の大型化 や高額化, 研究領域の細分化あるいは情報量の爆発的 増加等により, 一研究室内で研究を完結することが困 難となっている。 また, 臨床開発においても一医療機
関のみで実施することは困難になってきている。これ らを背景としたアカデミアに打けるオープンイノベー ションを, (1)機関として共同研究・共同利用型, (2)治 験・臨床試験実施のためのネットワーク型, に分けて まとめる。

\section{1）共同研究・共同利用型}

TRが盛んになっているが，キーとなる分子の制御 を化合物で行う場合, 多種の化合物, すなわち「化合 物ライブラリー」を用いたスクリーニングが不可欠で ある. 東京大学創薬オープンイノベーションセンター では約 21 万種類の化合物を揃え, 研究者に提供して いる(5)。これにより, 研究者はアカデミアでは従来 実施することができなかった大規模スクリーニングを 実施することができるようになった。 また，共用のス クリーニング設備も備え, 効率的なスクリーニングの 支援等も行っている. 同センターは, 東京大学総長室 の下に設けられた総括プロジェクト機構の 1 つであり, 特定の学部の組織ではなく共同利用に特化した組織・ 運営となっている.

文部科学省は, 個々の大学の枠を超えて大型の研究 設備や大量の資料・デー夕等を全国の研究者が共同で 利用したり, 共同研究を行うシステムの必要性を認識 し, 推進するために「共同利用・共同研究拠点」を選 定している (6). 平成 26 年度は 46 大学 95 拠点 107 研 究施設が認定され，それぞれの施設の特長を活かした 研究の機会を提供している。このうち, 「医学・生物 学系 (医学系)」が主として創薬に関連し，18 施設が 選ばれているがいずれも附置研・附置センターであり, 特定の研究対象や疾患領域に特化して専用の機器設備 や専門的人材を揃えている. 他機関の研究者は, 当該の 施設の研究者と共同利用および共同研究として連携す ることにより，各種リソースを活用することができる. 2）ネットワーク型

近年, 医師主導治験実施数が増加しているが, アカ デミア発シーズの場合には製品としての規格決定, 治 験実施に必要な薬理試験 - 安全性試験等の非臨床試験 のデザインの決定と実施, あるいは医薬品医療機器総 合機構 (PMDA) との薬事戦略相談等の企業主導治験 では実施したことのない業務を行う必要がある。また， 再生医療やがん免疫療法等の細胞治療, ウイルス療法 を含めた遺伝子治療, 核酸医療等, 製薬企業であって も開発経験のそしい新規治療法が多い.いかに優れた シーズであっても研究者が独力で, あるいは 1 機関内 で全てを実施することは不可能な状況となっている.

アカデミア発のシーズである TR を実施する拠点を 整備するために, 文部科学省は平成 19 年に「橋渡し研 
究支援推進プログラム」を開始し, 平成 24 年からは第 二期プログラムとして「橋渡し研究加速ネットワーク プログラム」となった，後者では，拠点の機関内のみ での開発だけではなく, 拠点外の他医療機関の研究支 援を遂行したり，拠点間の連携を強化することによっ てトランスレーショナルリサーチの迅速かつ適切な実 施を目的としている。 また, 厚生労働省では日本発の 革新的医薬品・医療機器創出のために世界に先駆けて 人体に初めて投与する臨床試験の実施体制を疾患領域 毎に整備する「早期 - 探索的臨床試験病院」と, 複数 病院からなる大規模なネットワークの中心となり臨床 研究の拠点となる「臨床研究中核病院」を整備し, 行 政的に機関を支援するオープンイノベーションの中核 形成が進められている.

「橋渡し研究加速ネットワークプログラム」では, シーズの開発段階によって下記のようにシーズのパイ プラインを分類している.

(1)シーズ A : 関連特許出願を目指す基礎研究課題

(2)シーズ B : 非臨床試験での Proof of Concept (POC)

取得および治験届提出を目指す医薬品および医療機 器の研究課題, あるいは薬事申請用臨床デー夕取得 を目指す対外診断用医薬品の研究課題

(3)シーズ C : 臨床で POC 取得を目指す研究課題

表 2 に各段階で必要とされる支援の内容を示す。 シーズ A（基礎研究）の段階では, 出願に必要な実験, 出願による特許成立の目処, 競合技術の調査, あるい は出願時の戦略（主張する権利範囲等）等の助言を行 う必要があり, バイオ, 製薬に通じた弁理士の支援が 欠かせない。シーズ B (非臨床試験) の段階では, 細 胞・動物を用いた Mechanism of Action の検証や POC の取得が必要であるが, どのような細胞・動物系で何 を指標として検証するのかという研究の立案支援が必

\section{表 2 各研究段階で必要となる支援の項目}

基礎研究段階から（シーズ A から）

- 知的財産権確保 (必要な研究, 弁理士相談, 競合特許調査等含む) . 研究費獲得

・研究倫理および利益相反管理

非臨床試験段階から（シーズ B から）

· PMDA 薬事戦略相談等の規制対応

・臨床試験を実施するために必要な非臨床試験の計画立案, GLP 準拠施設への委託

・非臨床試験に必要な製剂の確保

・製剤の規格決定，製造工程の決定，品質保証等の決定

臨床試験段階から（シーズ C から）

・臨床試験のデザイン・立案

- 実施計画書, 説明同意文書, 治験薬概要書等の資料の作成

・治験届け, 実施計画書の変更等における PMDA 提出書類の作成

・データマネジメント, 解析等の体制確保

・モニタリング, 監査等の品質管理・品質保証実施

・投与製剂の確保（細胞製剂では多くの場合，自施設での製造体 制整備が必要)
要である。また，治験を実施するためには各種法規・ ガイドラインに則った非臨床試験を計画し，実施また は委託について支援する必要がある。また，臨床での 使用と一貫性をもった規格を設定した製郕を調達する 必要がある，細胞製剂の場合では，多くの場合，アカ デミアの細胞調製施設（CPC : Cell Processing Center) での製造が行われているが，設備・構造だけではなく， 規格, 品質, CPC に習熟した専門家の従事あるいは支 援がないとこれらを運営することはできない. シーズ C (早期臨床試験) およびそれ以降の大規模試験の段 階では, 規制当局対応, 治験調整事務局機能が必要と なり, データマネジメント, データ解析，モニタリン グ，監査等のデータの収集と解析および試験の品質の 保証・管理業務も必要となる。上記の各種専門家をア カデミアが確保するようになってきており，体系的に 運営することによりアカデミアであってもシーズ探索 から大規模治験まで支援することが可能な支援組織,

すなわち ARO (Academic Research Organization) と して機能している機関もある. ARO は自施設内の支 援だけではなく, 他の医療機関からの要請を受けて支 援することも求められ始めており, オープンイノベー ションの場としての役割を担い始めている.

我が国において, 治験ネットワークを形成し, 被験 者の組み入れ促進が推奨されてきた.アアカデミア発の シーズの特徴の 1 つはアンメット・メディカル・ニー ズの疾患を対象とすることが多いことであるが，この ような患者は大学病院等の大規模かつ研究指向の医療 機関に集まることが多く, 従来の地域治験ネットワー クでは十分な被験者を集めることが困難であった。ア カデミア発の TR 開発では幾つかの障壁が存在するが, 開発を促進するために, 橋渡し研究加速ネットワーク プログラムでは, 拠点間・拠点内でのネットワーク形 成を行っている，同プログラムでは，(1)被験者リク ルート促進体制の構築，(2)相互モニタリング体制構築， (3)共有リソース活用, から成り立つ「ネットワーク構 築事業」を展開している(7). (1)では, 拠点が EDC (Electronic Data Capture）システムを用いて治験の被 験者となりえる疾患の患者を登録し, 症例集積の促進 を図っている。（2)では，モニターを同事業にて教育す るとともに共通 SOP の作成を行い, また, 拠点相互で のモニタリングを通じて医師主導治験も担当すること のできるモニターを各拠点に配備することを目指して いる. (3)は，オンラインカタログ整備（人材リソース の共有）と CPCの共同利用を目指している. 前者は拠 点に在籍する人材を Web 上で検索し, 業務の依頼等を 行えるようにするもので，外部のヒューマンリソース 
の活用促進が目的である，後者は，細胞調製を必要と する治験においても多施設共同試験の実施を可能にす るあるいはキャパシティーの限られた CPCにおいて 細胞調製の外部委託を可能にし, より有効に施設を活 用することを目指している，本事業での拠点間の相互 連携により，より効率的で迅速なシーズ開発が実現さ れることが期待されている.

このようなアカデミア間のネットワーク形成による 連携は,「ARO 協議会」,「国立大学病院推進会議」で も盛んに検討されており，もはや TR 開発において 「象牙の塔」では立ち行かなくなっているのが現状で ある。

\section{5. まとめ}

米国では NIH 主導でアカデミアのリソース活用と ネットワーク形成が行われてきており, 我が国でも急 速に整備が行われている. 日本のアカデミアの基礎研 究力および各方面での開発能力は国際的にも十分通用
する．様々な形態のオープンイノベーション，すなわ ち連携が進むことにより, 医薬品開発競争激化のなか で日本の競争力が向上することが期待されている.

著者の利益相反：開示すべき利益相反はない.

\section{文献}

1) 医療分野研究開発推進計画. 健康 - 医療戦略推進本部. 平成 26 年 7 月 22 日. http://www.kantei.go.jp/jp/singi/kenkouiryou/ suisin/ketteisiryou/dai2/siryou2.pdf

2) Henry Chesbrough. Open Innovation The New Imperative for Creating and Profiting from Technology. Harvard Business School Press 2003.

3）ファイザー 社. http://www.pfizer.co.jp/pfizer/company/ press/2014/2014_10_24.html

4) 国立がん研究セシター. http://www.ncc.go.jp/jp/information/ pdf/20110719.pdf

5) 東京大学創薬オープンイノベーションセンター. http://www. ocdd.u-tokyo.ac.jp/gaiyo.html

6) 文部科学省. 共同利用 - 共同拠点http://www.mext.go.jp/a menu/kyoten/

7) 文部科学省橋渡し研究加速ネットワークプログラム. 厚生労 働省早期 - 探索的臨床試験拠点整備事業/臨床研究中核病 院整備事業. 平成 25 年度成果報告会 抄録集. 